University of Louisville

ThinkIR: The University of Louisville's Institutional Repository

$5-2014$

\title{
Student government leadership in the 21st century : its importance and why it must be supported.
}

Spencer Scruggs

University of Louisville

Follow this and additional works at: https://ir.library.louisville.edu/honors

Part of the Educational Leadership Commons, and the Leadership Studies Commons

\section{Recommended Citation}

Scruggs, Spencer, "Student government leadership in the 21st century : its importance and why it must be supported." (2014). College of Arts \& Sciences Senior Honors Theses. Paper 80.

http://doi.org/10.18297/honors/80

This Senior Honors Thesis is brought to you for free and open access by the College of Arts \& Sciences at ThinkIR: The University of Louisville's Institutional Repository. It has been accepted for inclusion in College of Arts \& Sciences Senior Honors Theses by an authorized administrator of ThinkIR: The University of Louisville's Institutional Repository. This title appears here courtesy of the author, who has retained all other copyrights. For more information, please contact thinkir@louisville.edu. 
Student Government Leadership in the 21st Century: Its Importance \& Why It Must Be Supported

By

Spencer Scruggs

Submitted in partial fulfillment of the requirements

for Graduation summa cum laude

and

for Graduation with Honors from the Department of Psychological and Brain Sciences

University of Louisville

March 14, 2014 


\section{Student Government Leadership in the 21st Century: Its Importance \& Why It Must Be}

\section{$\underline{\text { Supported }}$}

Ever since the Morrill Act passed by Congress in 1862 and signed into law by President Abraham Lincoln, higher education has been a crucial topic of importance and debate. With the passage of this act, states created elaborate and publicly-supported systems of institutions of higher education to expand the reach and accessibility of a college education (Whisman, 2011). A pillar of this public sector of higher education has been shared governance, which implicates a collaboration between all members and involved parties of a university, to include faculty, staff, administrators, government officials and students, to direct the vision and work of the institution (Schick, 1992). The natural and most organized method of representing the student voice in this shared governance model has been through student associations or organizations of student selfgovernance, popularly referred to today as Student Government Associations. In this method of representation, the students elect individuals that represent their specific interests and school into various branches, usually labeled Executive, Legislative and Judicial, similarly to the national system of governance. Those representatives are then charged with various tasks, including "serving as the voice of the student body to the institution's administration, overseeing student fees, supervising student organizations, and running campus programming” (May, 2010, 212). They are descendants from literary societies and honors societies from the birth of American higher education institutions (May, 2010). Because of their representative nature, student associations are tasked with ensuring that every student's voice and opinions are heard and present in the decision-making process on initiatives and decisions about the student-campusexperience. They are crucial to ensuring the importance of students and their needs in the future of the higher education institution, especially in the pressures that higher education faces today. 
Higher education has always been seen as a way to progress oneself into a career and get a good job. Now, more than ever, that statement is true. President Obama himself gave a speech in February 2012 at a community college about the importance of higher education in the link to employment. Referring to the lack of employment due to lack of skilled workers, Obama (2012) said:

I hear from business leaders all the time who want to hire in the United States, but at the moment, they cannot always find workers with the right skills. Companies looking to hire should be able to count on these schools to provide them with a steady stream of workers qualified to fill those specific jobs (n.p.)

The overwhelming opinion, as expressed by President Obama, is that higher education is a direct link to jobs and thus needs to serve as a preparatory for those jobs, teaching the skills and knowledge you will need when you are in that specific career. As President Obama shared during that speech, obtaining a higher education is more important than ever and this implicates a rise in the importance of the student in an institution of higher education (Obama, 2012). With more and more individuals pursuing an education out of necessity, the position and voice of students is itself is growing to greater importance, implicating an increasing relevance for Student Government Associations. In the demand for the skilled employees mentioned above and the current state of the economy, higher education institutions are faced with a culture issue: is it more important to get the funding necessary to produce these skilled workers or give students an exceptional campus experience, including academic and extracurricular experiences? In this debate, the role of a Student Government leader is complicated, forcing the leader to make a decision between what is best for the institution or what is best for their constituents, the students of that institution. For Student Government Associations to be a relevant and impertinent 
contributor to the improvement of the student experience in higher education, the importance of the student at an institution must align with an overwhelming support of student government and the individual leaders serving in it.

This study aims to explore why Student Government Associations are so important in the context of shared governance at a higher education institution and on the individual.

Furthermore, the study explores how supportive advisors and university administrators can add to the effectiveness and success of the mission of Student Government Associations. The research additionally focuses on how both of these concepts, in various forms, contribute to certain institutional cultures that support or ignore the importance of students. Using both current literature and the lived experiences of student government leaders and advisors, all evidence will lead to the final outcome of a proposed set of learning and developmental objectives. These include but are not limited to guidelines on support from advisors, support from the institution itself and how to better prepare leaders of Student Government Associations to face the challenges they will face from their institutions.

\section{Importance of Student Government and Student Leadership Development}

\section{Impact on the Individual}

While serving in student government can be and should be considered a selfless endeavor, it has been noted by many as a great opportunity for self-growth and professional development that many students want in their personal and professional lives. Kuh and Lund (1994) find that involvement in student government is beneficial to growing and gaining skills they call social and practical competence. Social competence refers to the ability to regulate one's emotions, thoughts and actions in various social contexts and the ability to learn and adapt in those same social contexts (Kuh \& Lund, 1994). In comparison, practical competence is a set 
of skills that one should use to live a purposeful and fulfilled life; these include decision-making, pursuing passions, effective communication skills, maintaining personal health and well-being and being economically and politically knowledgeable and informed (Kuh \& Lund, 1994). Kuh and Lund (1994) also saw, through interviewing students involved in campus governance, an increase in self-confidence and self-esteem, mainly attributed to the individualized experience that student government leaders can get through serving in student government. By choosing what initiatives they want to work on and what their focus is going to be during their term in student government, student government leaders feel pride in their work and a close tie to it, satisfied that they got the chance to work on something so close and near to their heart. Overall, Kuh and Lund (1994, pp. 8-12) demonstrate the ability for a student involved in campus governance to become a confident and competent leader through learning, growing and gaining leadership skills such as decision-making, selfless service to others, and the ability to work with others towards a common goal.

Another very important aspect of serving a student body through student government is learning to work with administrators and "supervisors", in the sense of individuals that have the final say on decisions that affect the campus, such as the University President, a Board of Governors or Trustees, or other university officials. In his dissertation, May (2009) interviewed various students that had served as a Student Body President at their college or university. One of things that he stresses is the different experiences and interactions with administration that each of these Student Body Presidents had. In regards to the student affairs professionals, including the Vice President for Enrollment Services, Dean of Students, Vice Presidents of Student Affairs and other student involvement and affairs administration, all participants claimed they had a fantastic relationship with them (May, 2009). Many even mentioned how truly 
supportive the administration was, providing "lots of mutual respect" (May, 2009, p. 251) and, as described by one student, "cared about me as a person...cared about my opinions" (May, 2009, p. 252). This collegiality extended to their relationships with the Board of Trustees, in some cases the body of most important officials at a university that truly determine the direction a university follows. Many of the former Student Body Presidents stressed the mutual respect and sincerity on the part of the board members (May, 2009). A more important note, as stated by one of the former presidents, is the importance of professionalism and respect in that relationship, as "you can make or break your year with...the board of trustees" (May, 2009, p. 258). Probably the most notable outcome of working with administrators as a Student Body President, gathered from the various interviews, was not only just working with different individuals, but working with their biases and decision-making approaches. Many of these leaders had to work with offices that had business-like models that were not always "student-friendly", but noted that they still had positive working relationships with these offices. Often, the administrators had their way of doing things, so the biggest thing shared by the Student Body Presidents was finding a way to work with the administrators, understanding their approach to decision making and mold recommendations to fit that model (May, 2009). Wilson (2010) noted through interviews of student government officers as well, found a similar importance on the relationships made in the position. Alternately, Wilson (2010) found that the majority of the student leadership development that former student government officers commented on took place in the process of making relationships. Many student government leaders learn from the experience and knowledge of advisors and administrators and use it to make their own decisions about the student body (Wilson, 2010). As in May's (2009) study, relationships with a higher university authority was stressed as well in Wilson's (2010) study, in this case, the College or University 
President. Open access to and collegiality with the college or university President was listed as a part of the experience as a Student Government leader that lead to a perception of success, a feeling of importance and development as a student leader and as a person. Relationships are arguably one of the most important things about serving as a Student Government Leader, as noted by the majority of the student leaders in these two studies commenting on the relationships they made and how well they worked with people as Student Body President or in another Student Government position.

Many of the studies conducted on gains from involvements in student government have discovered the personal and societal skills one gains from that involvement (Schuh \& Laverty, 1983; Kuh \& Lund, 1994; Bialek et al., 1998), specifically working with others and the peopleskills gained from such efforts (Kuh \& Lund, 1994; Bialek et al., 1998; May, 2009; Wilson, 2010) and an awareness of skills that shape one's leadership style, such as decision-making, communication-styles and developing a professional image (Schuh \& Laverty, 1983). However, most of these can be generalized to all involvement or most involvement on campus, including the alumni association student organizations Bialek et al. (1998) and his research colleagues studied and the Interfraternity Council and other student organizations Schuh and Laverty (1983) studied. Not much research exists on the topic of developed-skills special to Student Government leaders, but two newer and more modern concepts have risen as outcomes of college and have very unique applications to student government. Perspective-taking, defined by Reason (2011), is the ability to take "seriously the perspectives of others" and develop "competence in moral and ethical reasoning and action" (p. 1). It implies a social and moral responsibility in understanding where others are coming from, accepting those different approaches to the topic at hand, and work with those perspectives to achieve one unified goal (Reason, 2011). Reason explains that 
the Association of American Colleges and Universities adopted perspective-taking, among other traits, as a strategic focus to encourage universities to develop in their students, being perspective-taking is important for working in a diverse world that values numerous opinions and encourages unification of these opinions (2011). He also explains that the desire among students to learn this is also high, with $60 \%$ of students surveyed in a 2010 University of Michigan analysis of data collected at 23 universities using the Personal and Social Responsibility Inventory said that they felt strongly that perspective-taking should be an outcome of college (Reason, 2011). Thus, there is a need and a want for teaching perspective-taking in higher education, but is there an extension beyond the classroom. Many Student Government leaders would argue for that statement, citing their experience in Student Government, like many of the individuals in Wilson (2010) and May's (2009) studies. As mentioned previously, having to interact with administrators that come with different approaches to making decisions is a form of perspective-taking, in that they are challenged to understand where the administrator is coming from, and like one student mentioned in May's (2009) study, respect that position, and try to come to a consensus. May also explains how working with the Faculty Senate, the representational body of the faculty of the college or university, and the Student Senate, the representational body of the students of the college or university, also provided opportunities for Student Government Leaders to reach out beyond their own decision-making approaches and philosophies to work with others who may have other agendas or approaches (2009). It is inevitable that, as a Student Government leader, you will work with many people, and mostly people that have different viewpoint and perspectives than yours. The implications of working with these people and the benefit to those that decisions as a result of this position affect make the case for Student Government to be an excellent, if not the best, option for learning 
perspective-taking.

Secondly, the need for critical thinking among college graduates is ever more present. Flores et al. (2012) describe the importance of critical thinking development in higher education in their study. Using a constructivist development format, which helps us understand how we “develop as adults, how we learn in the educational system, and ultimately how we perform in leadership positions" Flores et al. (2012) explain that critical thinking is the link between what we have learned in our education and our ability to perform in a workplace; thus, it takes more than just an education to have success in a career (p. 213). Flores et al. argue that the missing piece is critical thinking and argues that the place to develop it is one's studies at a university or college. In regards to leadership and critical thinking, Flores et al. argue that lapses in ethical decision-making and thought processes can be alleviated through the process of rational critical thinking (2012).

One model of critical thinking, developed by Paul and Elder (2009), leads to the ability to alleviate such lapses. In the Paul-Elder Critical Thinking Framework, a critical thinker uses certain intellectual standards, like depth, significance, and breadth, and applies them to certain elements of reasoning, such as purpose, inferences, concepts and information, to develop some intellectual traits, like humility, autonomy, integrity and confidence in reasoning (2009). As a leader goes through the critical thinking wheel, they determine what their and other's biases are in a particular situation, what are some questions that need to be answered, what are the implications for a decision that is made, what are any assumptions being made about the situation, what is the purpose of making a decision in this situation and how can the decision and the situation be interpreted to yield results (Paul \& Elder, 2009). Paul and Elder (2009) argue that critical thinking is key to developing various intellectual traits, such as perseverance, integrity, 
confidence in reason, autonomy, fair-mindedness, and humility, all arguably important to the position of Student Government leader. Finally, Paul and Elder suggest some characteristics of a "Well-Cultivated Critical Thinker", which include raising "vital questions and problems, formulating them clearly and precisely", gathering and assessing "relevant information, using abstract ideas to interpret it effectively" coming to "well-reasoned conclusions and solutions, testing them against relevant criteria and standards", thinking "open-mindedly within alternative systems of thought, recognizing and assessing, as need be, their assumptions, implications, and practical consequences" and communicating "effectively with others in figuring out solutions to complex problems" (2009). These are all, arguably, part of the job of a Student Government leader, a sentiment shared by many of those who gave their accounts as Student Government leaders in May's (2009) and Wilson's (2010) dissertations. Thus, with a need to grow critical thinkers in higher education and the capacity for one to learn to critical think effectively in Student Government, one can see the importance of involvement in Student Government in developing critical thinkers in addition to perspective-takers.

\section{Impact on the Institution}

While many studies have been undertaken on the study of involvement in campus life and, in the cases above, Student Government, not much has been researched about the importance of Student Government to institutions. In most cases, Student Government is the entity that provides student services, through the collection of a student fee or fees (Cuyjet, 1994). In many cases, these services can include health services, academic-support services, such as tutoring, and extracurricular opportunities that engage students academically and recreationally, all of these being important to student development. Cuyjet also argues that student governance is a "conduit for colleges and universities to train students to be future 
leaders, advocates, and service providers for their fellow college and university students" (Cuyjet 1994; a cited by Wilson, 2009, p. 4). Being that preparing students as these "future leaders, advocates and service providers" is a pressure in higher education on universities and colleges, having a structured, present system for doing so, like Student Government, relieves this issue. Furthermore, there is an argument on whether the student is the customer. Regardless of whether the student is the customer or not, the business-model implicated in this mindset is present, especially in admissions, competing for enrollment of students (Kreuter, 2014). This phenomenon has led to universities relying more on a diversity in the services they provide students and how "flashy" and attractive their student services and facilities are perceived (Kreuter, 2014). Student Government is crucial to providing these attractive student services and painting the campus experience as one to be envied. One example of this concept here on the campus of State University is the student-led-and-financed construction of the new Student Recreation Center at State University, an aspect of campus life that has been used as a promotional item by administrators, from Admissions Counselors to the Vice President for Advancement to even the University President himself. An example is the development of the new Student Recreation Center at State University, a completely student and SGA-driven process and paid for by the students of the university. If it were not for the President-at-that-time and a few other key Student Government leaders, the Student Recreation Center would not be standing today. Without Student Government, a project such as this would not have been possible and could demonstrate the importance of Student Government to many university and college administrators across the nation.

\section{Importance of Advisors in SGA}

Most colleges and universities have some form of advising for student organizations. In 
some cases, this is just a formality, but in most cases, these advisors provide structure and administrative support to the group and mentor-mentee relationships that student leaders learn and grow from (Miles, 2011; Campbell et al., 2012). The advisor is a multi-faceted role, often serving as a "mentor, teacher, leader, supervisor, and follower" (Miles, 2011, Section “ Advising Student Organizations"). Probably the most important thing for an advisor to recognize is when to step back and let the students lead the particular group or initiative (Miles, 2011). Advisors, in this case, serve as a source of knowledge and advice, if the student leader asks for it, and a policy-enforcer, ensuring that that group stays in good standing and does not break institutional policies, state and federal law. But Miles takes it further by explaining why Student Government stands out from the basic student organization and the implications for advising Student Government Organizations and its leaders. Student Government Associations have higher implications and consequences for their purpose, which according to Miles (2011), is divided into four parts: "[they] must follow their responsibilities as outlined in the student government's constitution and by the institution," "student governments must follow responsibilities delegated to them by the leadership of their institutions," they must follow through on responsibilities deferred to them by other decision-making bodies," and "student governments are responsible for assigning students to committees and boards" (Unique Challenges of Student Government section). Because the importance of the Student Government functions, the role of the advisor itself is heightened in importance and responsibility. Miles first stresses the importance of an advisor knowing student development theory, because of the breadth of Student Government representing all students on campus, not just a specific group or demographic (2011). Knowing this can help the advisor give relevant, comprehensive advisement to aid the Student Government leader in making decisions for the whole student 
body. Recommendations made for Student Government advisors include "student government officers and administrators must be honest with each other," they should be "experienced and supportive individuals," "administrators should be inclusive and care about students," "administrators should maintain confidentiality, and "administrators should take the time to establish relationships with students" (Miles, 2011, Role of Student Government Advisors section). Ultimately, the role of advisor to Student Government might be the most important because of how much a Student Government leader relies on them for history, for precedent, for emotional and mental support and as a teacher. Thus, it is important that the advisor is qualified enough.

Beyond giving just advice and being a source of history and experience with Student Government, advisors to Student Government serve as mentors. "In the psychosocial mentoring process, the mentor serves as counselor, friend, and advocate, providing guidance, role modeling, and acceptance for the mentee" (Kram, 1985; as cited by Campbell et al., 2012). Most individuals who are interested in Student Government were drawn to it by the chance to make an impact on the university and the student body and the chance to be involved in the decisionmaking process at the university. The advisor/mentor of Student Government serves as a comrade in this, as usually the advisor is involved in the decision-making process at the university as well. The other important part of being a mentor is the acceptance aspect. As explained in May's (2009) dissertation, many students had or have a tough and rocky term as Student Government President because of the implications of the decisions being made and the inevitable angry constituents. The Student Body President and any Student Government leader is bound to make decisions that are not so popular among certain student groups. One former Student Government leader also shared her frustrations with the fact that she felt so alone, 
because of the confidential and exclusive information that she received (May, 2009). A

mentoring relationship can help alleviate this feeling of loneliness or self-doubt about the work one is doing based on the reactions of a portion of the student body (Campbell et al., 2012). Less frequently, faculty mentorship provides the same benefits, but are not as popular of an option due to accessibility (Campbell et al., 2012). Needless to say, faculty mentors are helpful to Student Government in that they provide a different perspective on university initiatives and decisions. As mentioned earlier by Reason (2011), perspective-taking is important for college students to have coming out of college and it is the Student Government leader's role to match the student body's priorities with the university's priorities, which include those of faculty and staff. Having a faculty advisor would offer the Student Government leader a unique perspective into the faculty of the university and better equip the student leader with the tools necessary to garner faculty and staff support and ultimately accomplish their goals.

\section{Importance of the Orientation of Institutional Culture}

Now, more than ever, there has been a debate in higher education about the intentions and purposes of higher education itself: the more traditional academia definition or a model that follows a free-market philosophy. Defined by the Cato Institute, market-driven education is determined by how close the institution approximates a free market; it is essentially how well they are accomplishing the task of educating students in a competitive market against their opponents, or other institutions (Kaklauskas et al., 2012). Basically, public universities are slanted more to a business-model, trying to manage a smaller budget and still managing to graduate students and pay salaries. This is not inherently harmful to students, as mentioned earlier in the "rat race" to provide more services and more amenities to students to increase enrollment. The survival mentality is going to take a university faced with this problem in one of 
two directions, towards a student-centered philosophy or towards a market-driven philosophy that ignores the student. This fundamental issue in higher education has great implication for the work and success of Student Government and its leaders. As Giroux (2008) argues, democracy and the democratic process, known in higher education as shared governance, is crucial and intrinsic to higher education itself and the idea of "higher education as a private consumer good" (Gorman, 2012, p. 73) is toxic because it diminishes the importance of, as mentioned before, perspective-taking to come to one unified decision, decided on by all representative entities of the university. While Giroux (2008) mainly refers to the faculty of a university losing their rights and entitlements, his argument can extend to Student Government and students of a university in general. In the "private consumer model", universities are more focused on budgets, how to get more funding, and how to exist in the now. This shifts the attention away from what students need, be it more classroom space, more residence halls, more parking or an increase in the services provided to students, to what the university absolutely has to provide students, a college education (Gorman, 2012). This complicates the roles of Student Government leaders, who are encouraged to use perspective-taking and to try to understand what university administrators are going through, making difficult decisions that could affect students negatively. However, the Student Government leaders also have to answer to their constituents and fight for them. The internal conflict a Student Government leader can feel, fighting between administrations that ignore legitimate student concerns and the student's opinions themselves, can cause much emotional distress and lack of self-esteem and confidence. With a 50\% increase in the college student population from 1970 to 2011, according to Time (2012), the importance of students and issues that relate to college students go up. However, in the market-driven approach, this increase in students lead to not only stagnant services, but a decrease in total services offered. 
Paired with two, three, and sometimes, four-fold increase in tuition costs plus an average of $13 \%$ decrease in state funding between 2006 and 2011, according to Time (2012), students face a less student-friendly and more daunting atmosphere in higher education, one that has implications for retention and the ability to pay off the debt in a stagnant and often under-paying job market (Au, 2012). The looming threat of unsurmountable debt and the quality of experience a student gets for that debt all lead to the college dropout problem. As Hunt and Tierney (2006) explain, there is a shared responsibility for that issue; this shared responsibility involves public investment and the federal and state governments, but also the institutions themselves. It is up to the institution to ensure that they are preparing students not only for a future career, but that higher education is preparing our future civic and social leaders in whatever field they go into (Pompper, 2006). Part of this responsibility, at an institution, falls upon Student Government and the elected representatives of the student body. However, if an institution is not accepting a portion of the responsibility described by Hunt and Tierney (2006), the students suffer and cause stress and frustration in the work of Student Government leaders, who themselves are growing and learning in the role and as a college student.

However, as mentioned earlier, a market-driven education is not intrinsically studentunfriendly. Gorman (2012) expounds upon institutional branding and how it has become important in higher education today. Brands require when "marketing a product that [it] is almost indistinguishable from others to find ways to differentiate itself. Secondly, brands offer consistency and reassurance. Third, and perhaps most important, brands foster empathy and help the consumer to define who they are" (Olins, 2000; as cited by Gorman, 2012). Gorman (2012) explains that branding goes beyond just identifying as an institution of higher learning, but encompasses all that an institution has to offer, including services, the people employed there 
and the values of those people and of the institution itself, presenting "them as being core to the university's identity" (p. 113). Branding is way to broadcast what the university is trying to accomplish and incorporates involvement from all constituencies at an institution, including the staff, faculty and students (Gorman, 2012). Branding relies on the concept of shared governance and buy-in from all members of the university community. It offers a way for an institution to be committed to academic excellence and frame their mission to a student-friendly perspective. As it guides the faculty and staff in their work, branding also can guide the Student Government leader in their work, aligning the Student Government Association's goals with the university's goals. Working in a harmonious environment, the Student Government leader learns and grows as a leader and as a person himself or herself in addition to feeling supported and important to the administration and the university as a whole. It is a win-win and proves that a university can accomplish the goal of educating and preparing students for future careers, but also support and nurture our nation's future civic and social leaders.

\section{The Purpose of the Study}

The intent of this study was to collect anecdotal data from former students of State University (a pseudonym for a mid-sized, public university located in the Midwest) who had served as an officer in the Student Government Association since the inception of the organization. These collected anecdotal stories provide a glimpse into the experiences of an officer in the Student Government Association and provide themes, from which the researcher can analyze the work of students in Student Government and the perceived level of support they received. This study aims to determine how critical thinking, perspective-taking, perceptions of support and conflict affect the perceived success and learning of officers of Student Government. Furthermore, the anecdotes will be used, in conjunction with previous research and literature, to 
develop a list of recommendations to prepare future officers of the Student Government Association and the administrators that they will work with.

\section{Definitions}

For this study, there are some terms that need to be defined:

- Student Government Association- a collective entity of elected and appointed representatives of the student body at an institution of higher education

- Student Government leader- a student who has served in Student Government in an executive office, in most cases a Vice Presidential or Presidential role; it is not, however, limited to those two roles and may encompass another larger, important role

- Student Government Advisor- a university administrator who provides advising and mentoring services to a Student Government leader

- Formal training- direct involvement in the molding of student and campus life through activities such as committee meetings, SGA Senate meetings, and Executive Board Meetings; it can include but is not limited to leadership classes, professional conferences, and instructional videos

- Informal training- personal interaction, observation or discussions with advisors and other student leaders or administrators; it can include but is not limited to a relationship with the Student Government Advisor, advice from and discussion with students and other student leaders, and advice from and discussion with former Student Government leaders

\section{Nature and Limitations of this Study}

This study follows a qualitative research approach, involving the use of an open-butsemi- structured interview. In this study, qualitative data provided by participants is reflective of 
their tenure as a Student Government leader and is insightful into what they accomplished and how important they felt about what they accomplished. This study will involve the descriptive examination of those "collective experience". Because of time constraints and the need for comparative, varied experiences, this study employs purposeful sampling.

\section{Design of the Study}

\section{Research Perspective}

This study follows a qualitative research approach. Given the need for depth and richness in experiences of Student Government leaders to provide anecdotal data about the Student Government experience, this approach was chosen as opposed to quantitative methods, which do not offer "a level of depth and substance from participants" (Smith, 2012, p.72). As mentioned before, the researcher is interested in the collective experiences and perceptions of former Student Government Leaders. According to Patton (2002), the importance of qualitative research lies in the descriptions of these collective experiences. In these are more than just words; feelings, attitudes, biases and vocal color all contribute to explaining the perceptions and memories of being a Student Government leader. All of these aspects are crucial to understanding what it is to be a Student Government leader and making the recommendations on how to better prepare future Student Government leaders. This descriptive nature of qualitative research is necessary to accomplishing the purpose of this study, as it provides structure and flexibility, and a depth of information (Patton, 2002).

\section{Participants}

This study explores the varied and unique experiences of former Student Government leaders and how it has shaped them as a person. Given this goal, purposive sampling was employed to ensure that the participants interviewed would provide "information-rich cases, 
which are 'those from which one can learn a great deal about issues of central importance to the purpose of inquiry" (Patton, 2002, p. 230). Four former Student Government Leaders, whose tenures range from the 1980 s to the late 2000 s and into the current decade, and a current Student Government Advisor, all of whom attended or work at State University, were purposefully sampled. All five participants were selected because of their familiarity and were or are known university-wide for their work with Student Government. Purposeful attempts were made to select diverse participants, both in gender, race and ethnicity, and the position(s) they served-in. These diversity categories range from male and female, to Caucasian, African-American and Indian, to serving on university committees, serving as a Student Senator, serving as a Vice President or serving as President.

\section{Research Design and Protocol}

After receiving Institutional Review Board (IRB) approval, data collection began as data was collected "to answer the research questions being asked and fulfill the purpose of the study" (Patton, 2002, p. 275). Using the proposed qualitative research method, through purposive sampling, an in-depth, open and semi-structured interview was conducted. Tompkins and Cheney (1983) explain that although interviews are by nature participants' retrospective accounts, they are critical to exploring why individuals behave the way they do, as well as the meaning assigned to those actions, an introductory email was sent to the participants, describing the study, inviting them to participate and providing them with some background information (Appendix A) and an Informed Consent Form (Appendix C) that they had to sign before the interview could be conducted. Waddington (2004) suggests working with participants to find a time that best suited their needs and responsibilities. With this as a guiding structure, interviews were conducted at a time most convenient to each participant. 
Due to participants' time constraints, interviews were conducted both face-to-face, by email, and by telephone. According to Mann and Stewart (2000) interviewing by phone allows greater access to participants who, because of limited resources, may not otherwise have been able to participate. Meho (2006) explained that "email interviewing offers unprecedented opportunities for qualitative research" and "can be a viable alternative to the face-to-face and telephone interviews" (p. 1293).

Each interview began with a greeting and asking permission to record the conversation. After getting their permission, they were thanked and informed them of their right to not answer a question and to end the interview if they felt the need. The researcher ensured the participants that their identity would be kept confidential through the use of pseudonyms and that confidentiality was of the utmost importance to the study. A level of comfort that comes with these statements is crucial to getting the participants to be honest and open about their experiences.

In using a semi-structured interview, the researcher was able to be structured but also flexible in interactions with the participants (Patton, 2002). By using open-ended and specific questions, the participants could be guided in their responses but also provide their own perspectives and have the freedom to share openly and honestly. "Generally, the interview questions were designed to yield responses about experiences, perceptions, opinions, feelings, and knowledge" (Patton, 2002). The interview questions were designed to address different aspects of each position, Student Government leader and Student Government Advisor, but still address the core aspects listed above. The interview questions were borrowed in their likeness from Wilson's (2010) research on the student's experience in Student Government at Snow College. The interviews were recorded and transcribed, totaling to 26 pages, double-spaced. 
The Constant Comparative Method was used to analyze the interview data. Through this method, analysis of what was being said occurs at the very same moment it was being said by making any notes or comments of relevance or interest, to mark their importance for further review (Patton, 2002). After the interviews were completed, transcripts of what was said were scanned for accuracy. Through thematic analysis, interviews were separated into snippets of data that translate into abstract ideas about the role of Student Government leaders or advisors and their experiences, which in turn connected to larger, overarching themes that define Student Government as a whole and a student-centric institutional culture. Owen (1984) suggests a theme is characterized by recurrence, repetition, and/or forcefulness.

\section{Results}

Using the Constant Comparative Method, every anecdote of the participants came down to three large and overarching themes: a) Personal Impact, b) Relationships and Working with Others, and c) Institutional Culture. These themes match and line up very well with the thematic areas of research and literature: a) Importance of Student Government and Student Leadership Development, b) Importance of Advisors in SGA, and c) Importance of the Orientation of Institutional Culture.

\section{Personal Impact}

Student Government leaders grow from their experience in the office. This theme serves to share that growth and learning in various ways. Interview questions were strategically designed to ask participants how they had grown in various ways, whether directly, such as “Consider your experiences as a Student Government leader; tell me about the leadership skills or traits you may have learned while you were involved at State University”, or indirectly, through the freedom and openness of answers by participants. These answers were further 
broken down into three abstract categories: "Skills learned during the tenure", "Selfdiscovery/Improvement of Self”, and “Tenure's Impact on Future”.

Skills learned during the tenure. Participants were specifically asked to expound upon the leadership skills they had prior to their term as a Student Government leader and then what they gained during their term, to clearly make that distinction and to demonstrate the unique skills that can be gained through serving as a Student Government leader. The first participant, Oscar, served recently as Student Body President and before, a Justice on the Student Supreme Court and on various committees at State University. He mentioned how, before he served as Student Body President, during high school, he "was an athlete...so of course you have to work with other people. Discipline for the same purpose" (personal communication, February 24, 2014), referring to his previous comment about teamwork. "Obviously, you can't train and get better unless you are discipline and run around...I was a soccer player. So, teamwork, discipline, tolerance" (personal communication, February 24, 2014). He also mentioned faith as a leadership trait that he gained before his tenure and how it helped him through his years in college. Oscar mentioned that during his term as Student Body President, he learn three things: planning, management and execution. He expounded upon these, mentioning that it is easy to participate and put effort into something, but planning was crucial to accomplishing goals; furthermore, management of a team and of the task as the head of a task force (Student Government) was part of the learning experience, leading to execution of said task, the final result (personal communication, February 24, 2014).

The second participant, Tasha, served in multiple positions, primarily as a Vice President, in the late 1980s and early 1990s. Tasha mentioned how, unlike Oscar, she learned leadership skills as the student body president at her high school, including "skills in planning, 
implementation and just, in general, how to lead others (personal communication, February 26, 2014). Tasha then mentioned how, during her years in Student Government, she "really learned how to work with administrators, working with the Dean of Students and Vice President of Student Affairs and other administrators and how their work and leadership styles (personal communication, February 26, 2014). Through her work in Student Government, she also gained a knowledge base of working diverse groups and addressing each sub-group's specific needs. The third participant, Daniel, who served as a Student Senator, a Vice President and the Student Body President in the mid-1980s, mentioned how they really did not learn any leadership skills before they came to college, as college and leadership development was never really pushed to him. He, however, described how he learned to work with professionals, particularly in Student Affairs, as Student Body President and, through leadership workshops, learned general leadership skills, like those mentioned by Oscar (personal communication, February 24, 2014). The fourth participant, David, served most recently of all participants, serving on various committee roles and as a Vice President in the late 2000s and into the current decade. David recalls that both before and during his tenure in Student Government, teamwork was his most important leadership trait and that it is in constant development throughout his life (personal communication, February 26, 2014).

All participants also were asked to expound upon their use of critical thinking during their term as Student Government leader. David described his experience with using critical thinking as: "You always had to analyze the motives behind student actions, and help incentivize attendance and involvement to promote a healthy campus living situation. This oftentimes took putting yourself in others' shoes, and working through their thought process (personal communication, February 26, 2014). Oscar described a vivid memory of when he had to use 
critical thinking to make a decision:

Yeah. At the beginning of my term, in August, we had a flood on campus. And that flood really damaged our Student Health Services and so we had to make the decision, pretty quickly, do we want to invest our student health fee in that particular facility or do we want to invest the money we saved up in the student health fee into building a new facility that was close to campus, but would be considered off campus. So we had to weigh the pros and con, the benefits of such a decision, went out and talked to students and got their perspective, weighed the odds, and made the decision to move to the facility to 3rd street, the 3rd street facility, right where the baseball stadium is (personal communication, February 26, 2014).

In addition to critical thinking, another outcome, as described by Tasha, was learning how to take other's perspectives and work with them. Tasha described a transformative experience that really opened her eyes to perspective-taking and working with a diverse population of student: There was a time, I think it came from being new to diversity, so to speak, even though that's where I was coming from as an African American. I was raised a Baptist, and I went to Catholic school my whole life. So my diversity perspective, as it relates to other religions, pretty much came in my life, you were either Catholic or Baptist. So one of the responsibilities of the Student Government SVP (Services Vice President) was to plan and execute the Top 5 Homecoming reveal. It was always the Thursday before homecoming and I had to sign the contract for the Belle of Louisville, work to get it promoted, and there you go...get the revenue, get the students down to the Belle, get on the Belle and have a party and the SAB group would reveal the Top 5 and there you go. Well it turns out, that this event happened on something that I know now, but I didn't 
know back then, called Yom Kippur. I mean, it was huge, I got called racist, it was written up in the Cardinal...it was a major ordeal. That we were planning this thing on a huge Jewish holiday. And I didn’t know any Jewish people in my life and I wasn't familiar with the Jewish holidays but when I learned about it, the holiday ends at Sundown. So we don't get on the Belle of Louisville until 7pm and that's almost sundown...so it was about just going back to the Belle and making our departure time at 7:30pm. But, uh, so that totally affected the entire thing, I mean we didn't realize how many Jewish students were at UofL. I just remember that being one of the major things that impacted me and it was a great learning experience...it was difficult at the time. (personal communication, February 26, 2014).

Self-discovery/Improvement of Self. In many cases, participants found that serving in Student Government helped them discover who they are. Their experience in Student Government became transformative for themselves. Many of the participants mentioned how, through Student Government, they found a passion for serving others. One participant, Daniel, mentioned that after hearing he was a model for Student Government Leaders years later after he served, he felt really good. Serving in Student Government gave him more confidence and pride in himself (personal communication, February 26, 2014). This echoed throughout the other participant's interviews, as they described how proud they felt of their accomplishments. Many of them were proud of themselves for sticking up for the student voice and having the courage to do so.

Impact on Future. In some cases, the participant's tenure in Student Government had a direct impact on their future. Tasha's service to students led her directly into the field of student affairs, going to graduate school for student affairs. She recalls a moment during her graduate 
studies where the president of her graduate program's institution came up to her and, after hearing about her tenacity and involvement in Student Government at State University, asked her not to get involved in student politics there (personal communication, February 26, 2014).

Daniel, while his service in Student Government did not lead him to a career of serving students, directly impacted his leadership style and has affected his career today. Daniel mentioned, how before his term as Student Body President, the previous presidents' leadership styles were offputting and antagonistic towards the university administration, which damaged relationships and collaboration. Daniel, on the other hand, worked to repair these relationships and served in a more understanding and collaborative manner. In turn, he did repair the rapport between Student Government and university administration and got much positive feedback about his leadership style. This did nothing but affirm his leadership style, which he continues to use effectively today in his career. His leadership style has gotten him to where he is, no small thanks to what he learned and gained from his tenure as Student Body President (personal communication, February 26, 2014).

\section{Relationships and Working with Others}

Student Government leaders cannot accomplish what they do on their own. They rely on a network of administrators, advisors, students and peers in Student Government to accomplish their goals and improve campus life. This aspect was reflected not only in the direct questioning about this aspect, but also conversational banter after questions that may not have been directly related to the formation of and interaction with-in these relationships. Three common abstract categories that resonated through the participants' telling of their experiences and perceptions were: a) Advisors, b) Administration, and c) Reciprocation in Making Relationships.

Advisors. All of the participants mentioned how crucial their advisor was to their success 
in the role of Student Government Leader. All of the participants claimed that their advisor had an open-door policy and that they could get in touch with their advisor at any point in time and would have an open ear and source of advice. Most of the participants mentioned that this went beyond just one advisor and that they considered most, if not all, of the Student Affairs professionals at-the-time their advisors, all having an open-door policy and all willing to impart advice and moral and emotional support. Tasha even mentioned being advised by former Student Government Leaders, which she found very effective in helping her tackle the demands of her position. While interviewing Matthew, a Student Government Advisor who has served in that position for 13 years, he said that, as an advisor, he often relies on past Student Government Leaders for help advising, encouraging the current Student Body President to keep in touch with past presidents and relying on them in times of need. Furthermore, he divulges his approach to advising as:

Well the first thing I tell them, as a transition to new leaders, is to help them accomplish their goals. I help them orient their goals and I really don't tell them what to do. I caution them at times, but I'm never like you have to do this, this particular way. I'm hands off at times. You know, [I] support them, encourage them when they are feeling down. I use the strengths and do a full orientation with the officers and that's often what characterizes my advising, through strengths. Sometimes, it is helping with those internal dynamic problems and helping the group of officers connect. But in general, just being supportive and encouraging as much as I can (personal communication, February 28, 2014).

This approach to advising is what many of the former Student Government Leaders shared with me in their interviews. There was nothing, but positive things to say about how well they felt supported and listened to by their advisors. 
Administration. Similarly, the participants shared positive attributes of the administration. While some never got the chance to work with either or both the President or the Provost, they felt that all administrators they worked with on campus were respectful and understanding, including the Board of Trustees. David gave his thoughts on interactions with the President and Provost, sharing:

The President and Provost were ALWAYS free to talk. They wanted to hear students' voices and students' concerns. They also talked in candor. If something seemed politically implausible, or monetarily difficult, they were straight shooters. They didn't try to beat around the bush. Some leaders may feel like they weren't on the students' side, but oftentimes I think those leaders lose sight of how many things the president and provost of a university must take into account. They have to look at the big picture in its entirety. And while immediately it may not appear that a certain course of action has the students' best interest in mind, in the long run, I had full faith that they were making the right decisions on behalf of the students (personal communication, February 26, 2014).

Daniel shared a similar sentiment in his experience with his Student Government Advisor by sharing an anecdote. During his first week as Student Body President, Daniel got a message from a law school student about a parking ticket that he had received. Eager to make a good impression, Daniel wrote up a letter to the head of the Parking Office and included the President and the Student Government Advisor in the correspondence. Later, Daniel sat down with the advisor and his advisor told him that he was there to help him accomplish what he wanted to accomplish, but that the right pathways needed to taken to do so and that is what he was there for (personal communication, February 26, 2014). As shared by many of the participants, success during one's year as a Student Government leader comes from the relationships you make with 
the administration and the lengths you go to connect with them and understand them.

Reciprocation in Making Relationships. Another common similarity shared among what was shared by the participants of the study was reciprocating the relationship-making process with others. As a Student Government leader, many of the participants found the opportunity to connect with their student constituents. Daniel made it his goal to make "Student Government meaningful, visible and relevant to the average student. We had a theme for that year that we had on our plastic clips- 1985: Dedicated to Students. You know, what my goal was to do something so that SGA would touch every single student at some point in time and they would say that's what student government does" (personal communication, February 26, 2014). For those that did not connect as well to the students, they explicitly mentioned that they had wished they would have talked more and made a closer relationship with the students and their different needs, like David said. In addition to the students, many have made attempts to create relationships with current and future Student Government leaders. Oscar mentioned how he enjoyed talking with the current Student Government leader at State University and giving them advice, as he feels the need to reciprocate what was given to him as a Student Government leader. As mentioned before, Matthew, the Student Government Advisors, stays in constant contact with former Student Government leaders, just in case he needs to call on one of them to help advise the current Student Body President, a situation that he says happens very frequently (personal communication, February 28, 2014).

\section{Institutional Culture}

Often, Student Government Leaders' success is affected by the different cultures within the university itself. The participants shared, quite frequently, their thoughts on how the university's values and what was deemed as important to the future of the institution affected 
how well they were able to work with others and accomplish their goals. Throughout these experiences, three abstract categories kept appearing: a) Conflict in the Position, b) Value and Impact of Their Work and c) Attitudes Towards Students \& Their Needs.

Conflict in the Position. While none of participants ever felt pressured to ignore their student constituents, many shared that they had encountered situations of great conflict. David described a problem that he dealt with that many Student Government Leaders face:

There were many times throughout the rec center process, when I had to balance conflicting desires of the students. Never did I feel I had to ignore my student constituents, but the hardest part about SGA leadership is being able to balance different desires and viewpoints, even within your constituency. Some student groups wanted to ensure the rec center would have certain amenities, others didn't want the fee to be too high, while others wanted as luxurious a rec center as possible (personal communication, February 26, 2014).

Not only did the participants share their experiences with conflicts among the student body, but they also shared experiences with conflict from administrators. Tasha explained how she and the University President did not always agree on some issues, but that there was always a mutual respect and understanding between the two. She explained how conflict was not always a bad thing and that often in conflict is where one succeeds the most, as in her case with deciding the vendors for the Student Union (personal communication, February 26, 2014).

Value and Impact of Their Work. Participants answered a various questions about their legacy and the impact of their work on the student body and the university as a whole. Many of them claimed certain achievements, including "Well, the SAC is still standing. I guess that is my legacy really" (Oscar, personal communication, February 24, 2014) and other physically- 
identifiable accomplishments, like a new Student Recreation Center. However, they also expounded on whether those really meant anything to the students; some mentioned it was hard to tell at the time, but coming back, they see it. Other mentioned how, thought they did not realize it at the time, the students were greatly impacted by the accomplishments. Matthew, the Student Government Advisor, shared the same sentiment, in that 'in the end, if they really care about what is best for the students and the university, not just as a resume builder or to pump oneself up, but if they truly care about the students, then I think they are more set up to be successful" (personal communication, February 28, 2014). When asked "Overall, did you feel that what you were doing as a Student Government Leader was important to the students?" David responded with:

Sometimes I think students lose sight of the fact that SGA is their voice, to the upper echelons of the university leadership, and don't realize how important their questions and concerns truly are to the administration. Sometimes I think SGA members themselves even forget the importance. Administrators always and always will give us credibility just by listening to us. It is important that we, as SGA leaders, always remember and understand that being that voice in the administration's ear IS our most important task and our most important charge (personal communication, February 26, 2014).

Attitudes Towards Students \& Their Needs. Most of the participants shared the idea that the administrators and university officials they worked with supported and cared about the students. It was reflected in Matthew's own interview; his passion for the students and serving them exhumed in his voice and his answers on the impact of Student Government. The most prominent example about the attitudes of administrators towards students and their needs comes from David, who said: 
Some leaders may feel like they weren't on the students' side, but oftentimes I think those leaders lose sight of how many things the president and provost of a university must take into account. They have to look at the big picture in its entirety. And while immediately it may not appear that a certain course of action has the students' best interest in mind, in the long run, I had full faith that they were making the right decisions on behalf of the students (personal communication, February 26, 2014).

The perceived success each of the participants felt they had had as a Student Government Leader is a testament to the importance of students to the administrators during those leaders' tenures.

\section{Discussion}

\section{Themes}

As mentioned before, the themes really resonated throughout the interviews and in-turn, support the literature in the field about Student Government Leaders and their experiences and growth in the positions they served.

Personal Impact. As this is the most studied part of involvement in Student Government, there is no surprise what was discovered among the four former Student Government Leaders' participation in Student Government. All of the participants grew significantly in their leadership styles, mainly due to practice and actually implementing and experimenting with various approaches to leadership and decision-making. In terms of whether there was a difference between those more-removed-from-tenure and those less-removed-fromtenure, there really was not one. Many of them claimed that they had learned similar leadership traits, such as planning and execution. While the methods by which they learned those traits may be different, the end result is the same. Furthermore, they all brought this growth into their careers and future, another consistent hallmark of the experience in Student Government. 
Particularly important to the role seemed to be the use of critical thinking and rationalizing each conflict and problem that they faced. This suggests the importance of critical thinking and its' outcomes, described by Paul and Elder (2009) as Intellectual Traits, which ultimately end as a well-thought-out, all-encompassing decision. Because of the implications of decisions made upon the part of Student Government and how many are affected by said decisions, it is no wonder why critical thinking is reflected upon as crucial to the role of Student Government leader.

Relationships and Working with Others. Similarly, participants had very similar experiences in terms of relationship building with administrators, advisors, students, and former Student Government leaders. When compared with the accounts of experiences as Student Government leaders in both May (2009) and Wilson's (2010) dissertations, one can find a reoccurring importance on the building of relationships to the position. It is mentioned more often than any other aspect of the position, including any personal growth and benefits the student serving receives. In both this study and May (2009) and Wilson's (2010) studies, students reflect on their successes being possible because of the positive and supportive relationships they created with their advisors and other administrators. The relationships offer insight that the Student Government leader would not normally have and provide him or her with a source of $100 \%$ support, something that is invaluable in times where one questions what they are doing or is under fire from the student constituents about a particular event that occurred or policy that was made. In regards to whether there was a difference between those more-removedfrom-tenure and those less-removed-from-tenure, again there really was not one, which suggests another universality in the position and what it offers to those that serve in it.

Institutional Culture. This is where the literature and this study's findings begin to 
separate slightly. Both the literature and this study support the idea that a student-friendly culture at a university allows a Student Government leader to perform their task of serving as the voice of the student body much easier. It causes them less stress and allows a more open and conversational dialogue and debate over campus issues to occur. However, studies such as May (2009) and Wilson's (2010) have sampled students that have found that the culture at their institution to be not as student-friendly and very off-putting, disregarding the student's voice and even portraying a rude attitude towards any students sharing their opinions. In this study, all of the participants agreed, to some extent or another, that the culture at State University was very supportive and friendly towards students, noting that when the students' suggestions were not followed, it was not out of spite but rather out of a reality that things had to be a certain way. Furthermore, this same phenomenon could be extended the value or impact felt of the accomplishments of their term.

I hypothesize that this reflects a subjectivity in the idea of an institution's culture. While people like David may recognize that sometimes, what the students want cannot be accomplished because of extenuating circumstances and harsh realities, some Student Government leaders may not take this for an excuse and instead demand that there is a way to accomplish what thes students want. This subjectivity makes it hard to measure whether there is a true difference in institutional culture between when those more-removed-from-tenure served and when those lessremoved-from-tenure served. Is it plausible that, because of the current situation in higher education, compared to a couple decades ago, that institution culture has changed and that orientation of institution culture can affect how well a Student Government leader does during their tenure? The literature says yes, but the in-vivo accounts of experiences say there is not a difference between the two "eras". 


\section{Implications}

Based on the literature and research conducted, there is not a standardized system of Student Government and the working of it, not does there need to be. One of the hallmarks of Student Government is its' varied forms and operations to fit and mold the students of a particular university and their needs. But the universality of aspects of the experiences of Student Government leaders, as explored in the numerously mentioned studies above and this study itself, lend itself to the development of strategic learning and developmental objectives.

Each and every Student Government leader is different and their experience should be tailored to their idiosyncrasies. Earlier explained by Matthew, the Student Government Advisor, each Student Government leader comes in with a set of strengths that they can use to accomplish their goals. Often their goals align or will align with these strengths. The role of a Student Government Advisor should be help Student Government leaders find their strengths and guide them on how to use them to their advantage. Often, their strengths can help alleviate conflict, make decision-making easier and make teamwork easier, as one Student Government leader will have to rely on others with different strengths to get the job done.

\section{A Student Government leader should "transform" in some way or another by the} end of the term. As explored above, the experience of serving as a Student Government leader is transformative because of unique opportunities to work with others and the skills and tools one has to use while in the position. By all means, this should not be deliberative on the part of the Student Government leader, as their number one focus should be the students. However, the Student Government Advisor should challenge the student and push them to help facilitate this change.

\section{Critical Thinking is of key importance to develop and utilize as a Student}


Government leader. Many of the participants in this study cited critical thinking as key to helping make decisions. If Student Government leaders are encouraged to use the Paul-Elder critical thinking framework (The Wheel), they will find that clearer and more well-thought-out decisions will be made throughout their term (Paul \& Elder, 2009). This proves beneficial for those that are affected by the decision, students mostly in this case. Jumping to a decision based on gut should not be encouraged unless in real extenuating circumstances. The Paul-Elder critical thinking framework will also help the Student Government leader develop intellectual traits, such as humility, perseverance, integrity, courage, fair-mindedness and confidence in reason, all traits that prove to be beneficial when working with administrators or in times of conflict or adverse situations.

\section{Perspective-Taking is also of key importance to develop and utilize as a Student}

Government leader. As Student Government leaders serve a whole student body and in most cases a very diverse student body, they will often come to find that students have varying opinions. When serving a large student body, ensuring every student's need is met is of utmost importance. Thus, perspective-taking is crucial to understanding where a student is coming from and recognizing the next steps to take to make sure this student's needs are met and that he or she feels their voice is heard. Perspective-taking is also important on an administrative level, as Student Government leaders will work with various administrators that have varying opinions and perspectives on things. Being able to understand where they are coming from and figuring out common ground is crucial to accomplishing one's goals as Student Government leader.

\section{Relationship-building is the most important thing a Student Government leader can}

do. Being able to work with others and building rapport among others is of utmost importance to Student Government leaders because their initiatives are dependent upon a network of supporters 
who can get them in touch with the right people who can enact the change for them. Establishing trust will go a long way to building allies, which make accomplishing what the student body wants that much easier. Administrators have the choice on whether to work with Student Government or not, as much as some people want to believe that or not; Student Government is important to institutional unity, but administrators can choose whether they want to invest their time, energy and institutional money into Student Government initiatives. If Student Government leaders are intentional in setting up trustworthy and thoughtful relationships of mutual respect with administrations of their university, it goes a long way into setting up the success of Student Government initiatives.

Institutions should aim to be more student-centric. Based on the evidence from the multiple studies listed earlier, it is clear that Student Government leaders are more effective in their pursuits if the universities they serve at are more student-friendly. Student-friendly is very vague, as many can perceive it as the students get their way in every decision. To lessen this perception, the researcher suggests that by student-friendly and student-centric, they mean that the university makes decisions that will least impact the student body in a negative way. In essence, the university tries to lessen any negative impact on the student body and make decisions that will have a positive impact on the student body. While the debate is out on what that exactly means, we can say that a Student-Centric University is one that does everything with the students in mind, from the faculty to the staff to the researchers to Student Affairs to Student Government to even the managerial and custodial staff. Regardless of how much tuition costs and how expensive attending can be, Student-Centric Universities give students bang-for-theirbuck by preparing them academically, civically, socially, emotionally, and mentally to be better, more engaged citizens. If a university can claim they are doing this, the institution may find that 
the shared governance system is an effective and successful one and that Student Government leaders can effectively represent the student body.

\section{Limitations and Future Research}

While recommendations have been made for Student Government leaders, it is important to remember that this was a qualitative study and therefore, does not imply causation. It is not necessarily true that a Student-Centric Institutional Culture will cause Student Government leaders to be more effective in representing their student constituents. There are many outlying circumstances that could render that assertion untrue. Also, as noted earlier, interviews provide a depth of information necessary for this study, but they do not necessarily show the whole picture. It is possible that the experiences of these four participants are extraordinary in nature and do not represent the experiences of Student Government leaders as a whole. The scope of those interviewed is also a limitation, as only four former Student Government leaders were interviewed and only one advisor was interviewed. Again, it is possible that these five collective experiences are not representatives of Student Government and its' workings as a whole.

Secondly, attempts were made to avoid selection bias, but considering extenuating circumstances, some of the participants interviewed were individuals with whom the researcher had previous contact with and worked with. Qualitative researchers interact with the research context and participants and construct the interpretations of those studied (Mishler, 1986). However, reasonable attempts were made to remove any bias and collect a diverse sample to represent a diverse class of Student Government leaders. Lindlof and Taylor (2011) explained that "researchers often fuse their personal interests with their professional pursuits" therefore, personal experiences and interests can often aid the qualitative researcher to better understand what is important or relevant in the study (p. 76). 
Further research should continue to examine the effects of aspects of serving as a Student Government leader on an individual and on an institution simultaneously. Future research should make attempts to include more participants from diverse and different backgrounds and from various tenures. A reworking of interview questions and inclusion of more participants may yield results that can better prove a correlation between varying environments of higher education in different eras and the institutional culture and its effect on how well Student Government leaders function in them. Despite these fallbacks, the findings revealed in this study, for the most part, match up well with current literature on Student Government leaders and Student Government itself. These findings support the suggestion of learning and developmental objectives that can help guide Student Government leaders.

\section{Conclusion}

Student Governance and Student Government Leadership, while studied to a varying extent, has many implications for higher education that warrant its studying. If shared governance is truly a tenant of higher education, Student Government serves as the student voice in that model and implies a role of students in the decisions made by the university. The legacy of a university is its students and thus, it is important for the university to ensure that legacy is a strong one. As Student Government is the voice of students, universities can rely on Student Government to ensure the student campus-experience is a satisfying and fulfilling one. Finally, if a university's goal is to nurture and develop future civic leaders and engaged citizens, there is not a better place to do so than through Student Government, teaching and conferring skills and leadership traits that one will need later on in life.

In the importance of Student Governance, there is an importance in developing the Student Government leader. Thus is the motivation and inspiration for this study. This study 
aimed to determine what makes Student Government so important and relevant in higher education and how we could support Student Government leaders to match those reasons. An additional aim was to figure out if there was a noticeable difference between how Student Government leaders work and the support they receive between today and decades earlier. There was no noticeable difference in the term of tenure and how Student Government leaders and the support they received, alternatively finding much universality and commonality between those that served most-recently and those that served in the role less-recently. However, using current literature and qualitative research of former Student Government leaders at State University using a semi-structured interview, the researcher was able to determine Student Government's importance and relevance to institutions of higher education and higher education itself. The results of accomplishments of Student Government leaders impact universities and higher education and are accomplished through three themes: a) Personal Impact or The Importance of SGA and Student Development, b) Relationships and Working with Others or The Importance of Advisors [and Administrators], and c) Institutional Culture or Importance of the Orientation of Institutional Culture. Without Student Government, institutions and higher education would lose a valuable entity that helps prepare our nation's future civic leaders and engaged citizens. Thus, it is important to ensure the success of Student Government and consequently, the success of Student Government leaders. By following the proposed list of learning and development objectives, Student Government Advisors and Student Government itself has a roadmap to ensuring the success of its leaders, in turn setting up the success of the institution and higher education itself. 


\section{References}

$\mathrm{Au}$, H. O. (2012). American higher education, high tuition, and high student loans: The debt implications for students during and after college case studies at the university of Hawai $i$. (Doctoral dissertation). Retrieved from http://search.proquest.com/docview/1347617355? accountid=14665. (1347617355). (Order No. 3569049, University of Hawai'i at Manoa). ProQuest Dissertations and Theses, 218.

Bialek, S. C., \& Lloyd, A. G. (1998). Post graduation impact of student leadership.(Report to American College Personnel Association). Retrieved from http://search.proquest.com/docview/62538700?accountid=14665

Campbell, C. M., Smith, M., Dugan, J. P., \& Komives, S. R. (2012). Mentors and college student leadership outcomes: The importance of position and process. Review of Higher Education, 35(4), 595-625. Retrieved from http://search.proquest.com/docview/1140129699?accountid $=14665$

Cuyjet, M. J. (1994). Student government as a provider of student services. New Directions for Student Services 66: 73-89. Retrieved from http://search.proquest.com/docview/62572980?accountid=14665

Dias, M. H. (2009). The leadership perspectives of former student government presidents and the post-college impact of the presidency. (Doctoral dissertation). Retrieved from http://search.proquest.com/docview/304881199? accountid=14665. (304881199). (Order No. 3349576, The George Washington University). ProQuest Dissertations and Theses, , 233.

Dunkel, N. W., \& Schuh, J. H. (1998). Advising student groups and organizations. The Jossey-Bass higher and adult education series Jossey-Bass Inc., Retrieved from http://search.proquest.com/ docview/ 62438812?accountid=14665

Flores, K. L., Matkin, G. S., \& Burbach, M. E. (2012). Deficient critical thinking skills among college graduates: Implications for leadership. Educational Philosophy and Theory, 44(2), 212-230. Retrieved from http://search.proquest.com/docview/1027033846?accountid=14665

Hunt, J., Tierney, T., \& Carruthers, G. (2006). American higher education: How does it measure up for the 21 st century? National Center Report number 06-02, National Center for Public Policy and Higher Education. Retrieved from http://search.proquest.com/docview/62091357? accountid=14665

Giroux, H., \& Polychroniou, C. (2008, Nov). Higher education without democracy? Tikkun, 23, 44-45. Retrieved from http://search.proquest.com/docview/212235248?accountid=14665

Giroux, Henry A. (2009-09). "Academic Unfreedom in America: Rethinking the University as a Democratic Public Sphere." Works and Days 26 and 27: 45-71. Print.

Gorman, B. B. (2012). Governmentality in higher education: A critical analysis of the national survey of student engagement (NSSE). (Doctoral dissertation). Retrieved from 
http://search.proquest.com/docview/1020132292?accountid=14665. (1020132292). (Order No. 3509744, Michigan Technological University). ProQuest Dissertations and Theses, , 256.

Kaklauskas, A., Daniunas, A., Amaratunga, D., Urbonas, V., Lill, I., Gudauskas, R., .. . Jackute, I. (2012). Life cycle process model of a market-oriented and student centered higher education. International Journal of Strategic Property Management, 16(4), 414. Retrieved from http://search.proquest.com/docview/1252702136?accountid=14665

Kram, K. E. (1985). Improving the mentoring process. Training and Development Journal, 39(4), 40. Retrieved from http://search.proquest.com/docview/227018918?accountid=14665

Kreuter, N. (2014, February 27). Customer Mentality. Inside Higher Ed. Retrieved from http://www.insidehighered.com/views/2014/02/27/essay-critiques-how-student-customeridea-erodes-key-values-higher-education

Kuh, G. D., \& Lund, J. P. (1994). What students gain from participating in student government Retrieved from http://search.proquest.com/docview/62552894?accountid=14665

Laosebikan-Buggs, M. 0. (2006). The role of student government: Perceptions and expectations. In Miller and Nadler (Eds.), Student governance and institutional policy: Formation and implementation (pp. 1-8). Information Age Publishing: Greenwich, CT.

Lindlof, T. R., \& Taylor, B. C. (2011). Qualitative communication research methods ( $3^{\text {rd }}$ ed.). Los Angeles, CA: Sage.

May, W. P. (2009). Student governance: A qualitative study of leadership in a student government association. (Doctoral dissertation). Retrieved from http://search.proquest.com/docview/304884460? accountid=14665. (304884460). (Order No. 3401608, Georgia State University). ProQuest Dissertations and Theses, , 502-n/a.

May, W. P. (2010). The history of student governance in higher education. College Student Affairs Journal, 28(2), 207-220. Retrieved from http://search.proquest.com/docview/1018479784? accountid=14665

Mann, C., \& Stewart, F. (2000). Internet communication and qualitative research. London, England: Sage.

Meho, L. I. (2006). E-mail interviewing in qualitative research: A methodological discussion. Journal Of The American Society For Information Science \& Technology, 57(10), 12841295. doi:10.1002/asi.20416

Miles, J. M. (2011). Reflections of student government leaders: Implications for advisors. College Student Journal, 45(2), 324-332.

Mishler, E. G. (1986). Research interviewing: Context and narrative. Cambridge, MA: Harvard University Press. 
Obama, B. H. (2012, February 13). Remarks by the President on the Budget. Presented in Northern Virginia, Virginia, United States.

Olins, Wally. "How Brands are Taking Over the Corporation." The Expressive Organization: Linking Identity, Reputation, and the Corporate Brand. Ed. Majken Schultz, Mary Jo Hatch and Mogens Holtenn Larsen. Oxford: OU Press, 2000. 51-65. Print.

Owen, W. F. (1984). Interpretive themes in relational communication. Quarterly Journal of Speech, 70, 274-287.

Paul, R., Elder, L., \& Foundation for Critical Thinking. (2009). The miniature guide to critical thinking: Concepts and tools. Dillon Beach, Calif: Foundation for Critical Thinking

Patton, M. Q., \& Patton, M. Q. (2002). Qualitative research and evaluation methods. Thousand Oaks, Calif: Sage Publications.

Pompper, D. (2006). Toward a 'relationship-centered' approach to student retention in higher education. Public Relations Quarterly, 51(2), 29-36. Retrieved from http://search. proquest.com/docview/222460969?accountid=14665

Reason, R. D. (2011). Expanding the conversation: Perspective taking as a civic outcome of college. Journal of College and Character, 12(2), 6. Retrieved from http://search.proquest.com/ docview/1037909629?accountid=1466

Riggs, L. W., \& Hellyer-Riggs, S. (2014). Development and motivation In/For critical thinking. Journal of College Teaching \& Learning (Online), 11(1), 1. Retrieved from http://search.proquest.com/docview/1477975513?accountid=14665

Schick, E. B. (1992). Shared visions of public higher education governance: Structures and leadership styles that work American Association of State Colleges and Universities. Retrieved from http://search.proquest.com/docview/62841826?accountid=14665

Schuh, J. H., \& Laverty, M. (1983). The perceived long-term influence of holding a significant student leadership position. Journal of College Student Personnel, 24(1), 28. Retrieved from http://search.proquest.com/docview/1295091009?accountid=14665

Smith, D. L. (2012). The First 100 Days in the Academy: An Analysis of the College and University Presidency During the Honeymoon Period. (Doctoral dissertation).

Time Staff. (2012, October 18). Degrees of Difficulty. Time. Retrieved from http://nation.time.com/ 2012/10/18/degrees-of-difficulty/

Whisman, S. J. (2011). The american government and higher education: An analysis of the morrill act, GI bill and the political speeches of president barak obama. (Doctoral Dissertation). Retrieved from http://search.proquest.com/docview/873277186? accountid=14665. $(873277186)$. 
Whitt, E. J. (1994). "I can be anything!": Student leadership in three women's colleges. Journal of College Student Development,35(3), 198. Retrieved from http://search.proquest.com/ docview/1295114810?accountid=14665

Wilson, G. N. (2010). Student leadership development within student government at snow college. (Doctoral dissertation). Retrieved from http://search.proquest.com/docview/ 814730874? accountid=14665. (814730874). (Order No. 3432022, Oregon State University). ProQuest Dissertations and Theses, 178. 
Appendix A

Interview Protocol \& Questions

\section{This background information will be discussed with each interviewee:}

This is a "phenomenological study" meant to study if there is a correlation between a rise in pressures of higher education and a rise in difficulty of the job of Student Government Leader. This means that the questions will address both "formal" and "informal" experiences which took place during your tenure as a Student Government Leader at State University . "Formal" means direct involvement in the molding of student and campus life through activities such as committee meetings, SGA Senate meetings, and Executive Board Meetings. "Informal" means personal interaction, observation or discussions with advisors and other student leaders or administrators. You will be asked to recall, to the best of your ability, the time you spent as a student leader in Student Government Association at the University of Louisville, and the experiences you had, good or bad, which may have molded your approach to leadership. You will not be personally identified in this study unless you choose to share information with others. You will be identified in this study by an alternate or pseudonym to help maintain confidentiality. You were given an Informed Consent form to review and sign. Do you have any questions or concerns that need to be discussed? Have you signed the form?

\section{Potential questions that may be asked during the interview:}

1. What years were you involved as a Student Government Leader at State University?

2. Tell me about any leadership skills or traits that you may have learned prior to your enrollment at State University .

3. Consider your experiences as a Student Government Leader; tell me about the leadership skills or traits you may have learned while you were involved at State University?

4. Describe one goal from your term as a Student Government Leader that you were determined to complete by the end of your term.

5. As a Student Government Leader, during your term, did you receive any type of formal training as a leader? "Formal training" can include but isn't limited to leadership classes, professional conferences, and instructional videos. If you did, could you explain what the formal training was like?

6. Tell me about any informal training you received as a Student Government Leader. "Informal training" can include but isn't limited to a relationship with the Student Government Advisor, advice from and discussion with students and other student leaders, and advice from and 
discussion with former Student Government Leaders.

7. Tell me about your relationship to other university officials, such as the President of State University or the Provost of State University. Were they generally supportive of your ideas and goals? How much contact did you have with them? How much time did they make for you?

8. Was there ever a time during your tenure were you had to make a difficult decision that could have affected the student body negatively, but benefit the university as-a-whole? Were you ever pressured to ignore your student constituents?

9. Was there a time during your tenure were you had to use critical thinking skills to work through a problem or issue among the student body or in campus life?

10. Overall, did you feel adequately prepared and supported during your term as a Student Government Leader?

11. Overall, did you feel that what you were doing as a Student Government Leader was important to the students? Did you feel that the campus administrators and students realized this importance?

12. Evaluate yourself as a Student Government Leader from your own perspective and from the perspective of a student during your tenure. Do you think you did a good job as a Student Government Leader? What would you change to fix or affirm that perception of your legacy as a Student Government Leader?

\section{Potential Questions that may be asked in an interview (Advisors):}

1. How long have you been an advisor to student government leaders?

2. How would you describe your advising style to student government leaders?

3. Did you have previous experience in student government yourself? If so, what positions did you serve in?

4. Have you used that experience in any way to advise past and current student government advisors? OR Do you rely on any past experiences to help you advise student government leaders?

5. If you had to determine one thing that prevents student government leaders from being effective representatives of their student constituents, what would it be and why is that the case? 
6. How do you think the turnover rate between student government administrations affects the perception of student government and it's ability to affect change on behalf of the student body?

7. What role does critical thinking play in student government?

8. What is one characteristic of the most effective student government leaders? 
Appendix B

Sample Recruitment Letter/Email

Student Government Leadership in the 21 st Century

Recruitment Letter-via e-mail

Dear [Mr. / Ms. LAST NAME],

I write to invite you to participate in a study on the effect of support of and pressures on Student Government Leaders, past and present. Student Government Leadership is, arguably, vital to a university existing and operating to the best of its ability. As a university considers important decisions about its future, it often turns to the Student Government Leaders for the student voice. Along with this can come pressure and, in some cases, a lack of support or the exact opposite. It is important that we study support of and pressures on Student Government Leaders so that we can better improve the campus and academic

We have contacted you because of your previous involvement in Student Government at the State University. We believe that you would have valuable information to add to this study. You are under no obligation to participate. However, if you would like to take part in the study, please let me know via e-mail. I will follow-up to schedule a time to interview you via phone. We anticipate the phone interview taking about 30 to 45 minutes. Should you agree to participate, I will send you a consent form that will need to be signed and returned either electronically or to the address listed below.

Thank you for your time and consideration.

Spencer Scruggs, Student

sescru01@louisville.edu

Vice President for Student Affairs Office

Student Activities Center W302 
Appendix C

IRB Assigned Number:

Uofl Institutional Review Boards

IRB NUMBER: 14.0087

IRB APPROVAL DATE: 02/13/2014

IRB EXPIRATION DATE: 02/12/2015

For IRB Approval Stamp

\section{Subject Informed Consent Document}

Student Government Leaders in the 21 ${ }^{\text {st }}$ Century

Investigator(s) name \& address: Dr. Glenn Gittings, Spencer Scruggs; University of Louisville, | Louisville, KY 40292;

Site(s) where study is to be conducted: Via Telephone

Phone number for subjects to call for questions: 502-852-6937

Introduction and Background Information

You are invited to participate in a research study. The study is being conducted by Glenn Gittings, Ph.D. with the help of student investigator, Spencer Scruggs. The study is sponsored by the University of Louisville, Vice President of Student Affairs. The study will take place via telephone. Approximately $\mathbf{5}$ subjects will be invited to participate.

\section{Purpose}

The purpose of this study is to understand the ways in which support from university administration and pressures of higher education can affect the job of student government leaders and their ability to represent their student constituents.

\section{Procedures}

In this study, you will be asked to share your perceptions and thoughts of your involvement in student government. You will be asked to participate in a semi-structured interview during which we will ask you about your perceptions and thoughts of your term of involvement in student government. We anticipate the interview taking about 30 minutes with a potential 15 minute follow-up if needed.

\section{Potential Risks}

There are no foreseeable risks, although there may be unforeseen risks.

\section{Benefits}

The information collected may not benefit you directly. The information learned in this study may be helpful to others.

\section{Compensation}

You will not be compensated for your time, inconvenience, or expenses while you are in this study. 
Student Government Leaders in the $21^{\text {" }}$ Century

Uofl Institutional Review Boards

IRB NUMBER: 14.0067

IRB APPROVAL DATE: 02/13/2014

Confidentiality

IRB EXPIRATION DATE: 02/12/2015

Total privacy cannot be guaranteed. Your privacy will be protected to the extent permitted by law. If the results from this study are published, your name will not be made public. While unlikely, the following may look at the study records:

The University of Louisville Institutional Review Board, Human Subjects Protection Program

Audio from interviews will be recorded for later transcription. Audio files will be stored in a locked cabinet in the principal investigators office. All identifying information will be removed from transcripts.

\section{Voluntary Participation}

Taking part in this study is voluntary. You may choose not to take part at all. If you decide to be in this study you may stop taking part at any time. If you decide not to be in this study or if you stop taking part at any time, you will not lose any benefits for which you may qualify.

\section{Research Subject's Rights, Questions, Concerns, and Complaints}

If you have any concerns or complaints about the study or the study staff, you have three options.

You may contact the principal investigator at (502) 852-6937.

If you have any questions about your rights as a study subject, questions, concerns or complaints, you may call the Human Subjects Protection Program Office (HSPPO) (502)

852-5188. You may discuss any questions about your rights as a subject, in secret, with a member of the Institutional Review Board (IRB) or the HSPPO staff. The IRB is an independent committee composed of members of the University community, staff of the institutions, as well as lay members of the community not connected with these institutions. The IRB has reviewed this study.

If you want to speak to a person outside the University, you may call $1-877-852-1167$. You will be given the chance to talk about any questions, concerns or complaints in secret. This is a 24 hour hot line answered by people who do not work at the University of Louisville.

This paper tells you what will happen during the study if you choose to take part. Your signature means that this study has been discussed with you, that your questions have been answered, and that you will take part in the study. This informed consent document is not a contract. You are not giving up any legal rights by signing this informed consent document. You will be given a signed copy of this paper to keep for your records.

Signature of Subject/Legal Representative

Date Signed

Signature of Person Explaining the Consent Form

Date Signed

(if other than the Investigator)

Page 2 of 3 
Uofl Institutienal Review Bsards RB NUMBER: 14.0067

Student Government Leaders in the $21^{\text {" }}$ Century

RB APPROVAL DATE: 02/13/2014

IRB EXPIRATION DATE: 02/12/2015

Signature of Investigator

Date Signed

LIST OF INVESTIGATORS

PHONE NUMBERS

Dr. Glenn Gittings

(502) $852-6937$

Page 3 of 3 